\title{
On The Study of Federal Capitals: A Review Article
}

Commonwealth Journal of Local Governance

Issue 6: July 2010

http:/lepress.lib.uts.edu.au/ojs/index.php/cjlg

\section{Roger Wettenhall}

Professor Emeritus in Public Administration and

Visiting Professor, ANZSOG Institute for Governance,

University of Canberra

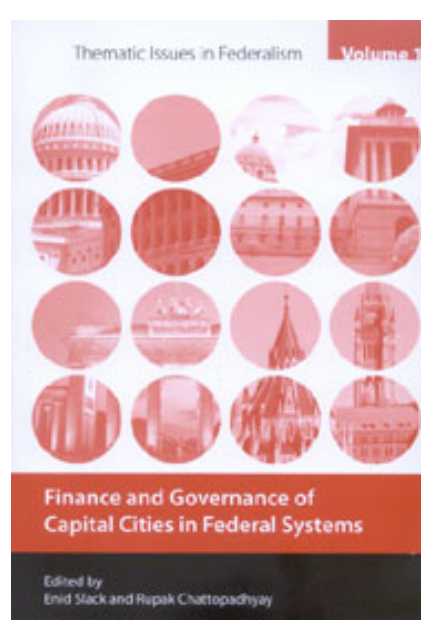

\section{Finance and Governance of Capital Cities in} Federal Systems

Edited by Enid Slack \& Rupak Chattopadhyay (McGill-Queen’s University Press, 2009).

It is fitting that Canada, as one of the world's leading federations, should play host to important ventures in the study of federal capitals, and in the analysis of how these capitals are governed and financed. A generation ago it was Canadian professor of political science Donald Rowat who produced the first anthology of these capitals. His edited book, with 17 case studies contributed by leading scholars of the time, provided excellent coverage of its subject and has remained the major text in the field for over 30 years. But there have been important developments in the field since Rowat's book was published by University of Toronto Press (Rowat 1973), and we can be thankful that another Canada-based team has produced a sequel volume that brings the story up-to-date and extends it in significant ways (Slack \& Chattopadhyay 2009). 
The new book is a product of the Ottawa-based Forum of Federations, which has a range of relevant conference, publishing, educational and consulting activities. It has previously comprehensively explored the subject of local government and metropolitan regions in federal countries, leading to a range of conferences and publications. The Canadian enterprise in this general area is further demonstrated in the hosting of a broader study of capital cities - not just federal capitals - with an important book published in 1993 (Taylor et al 1993).

Rowat's 17 federal capitals were Belgrade, Bern, Bonn, Brasilia, Buenos Aires, Canberra, Caracas, Delhi, Islamabad, Kuala Lumpur, Lagos, Mexico City, Moscow, Ottawa, Vienna, Washington and Yaoundé (Cameroon). But political changes over the 30-year period have eliminated at least one federation (Yugoslavia) and seen others relocate their capitals in major metropolises (Bonn to Berlin) or away from them (Lagos to Abuja). The new anthology focuses on just eleven, making these adjustments and as well replacing Yaoundé with Addis Ababa (Ethiopia), adding Cape Town and Pretoria (which share the capital function in South Africa), and dropping the two South Americans and Moscow as well. Does that mean that their countries have ceased to be federations?

There can be no absolute answer to that question, because federal status is not always a black-and-white matter. Certainly the Soviet Union has gone, but Russia still calls itself a federal republic. Through the 1970s and '80s we were often told that Spain was decentralising so substantially that it was turning itself into a federation, but it is Belgium that gets the nod as a new European federation, not Spain. And what about the United Arab Emirates? They look more like a federation than a union, but they do not appear in any of the collections under consideration here.

Donald Rowat visited Canberra several times, and in an exercise commemorating the first anniversary of self-government in the Australian Capital Territory he repeated his original list with one change: Cameroon, he said, had turned itself into a unitary state, so the number now stood at 16 (Rowat 1991: 28). ${ }^{1}$ He was a committed scholar in the best sense, and I cannot resist intruding a personal note into this review. I found myself sitting next to him at a congress of the International Institute of Administrative Sciences in Mexico City in 1974. Federation was under discussion, and an Italian professor made

\footnotetext{
${ }^{1}$ In the 1993 capital cities study noted above, he contributed a chapter on federal capitals, now featuring Washington, Canberra, Delhi and Ottawa as his case studies (Rowat 1993).
} 
this remarkable declaration: "Everyone knows that federalism is dead and buried." As a good Canadian federalist, Donald was incensed, and as a good Australian federalist I was not far behind. However we were both upstaged, for our Mexican hosts protested even more vehemently than we could have done. We may previously have entertained some doubts about the strength of Mexican federalism, but this experience prompted serious reconsideration!

This review is mainly about the new book, but it too acknowledges Rowat's pioneering work in the field. His opening paragraph in the 1973 book, quoted in the Introduction to the new book, provides the necessary clothes-hanger for all subsequent work in the field: the federal government, '.. wants to control and develop the capital in the interests of the nation as a whole, while the people of the capital naturally wish to govern themselves to the greatest extent possible', (Rowat 1973: xi; quoted in Slack \& Chattopadhyay 2009: 4).

So, as the editors of the new book point out, federal governments have experimented with a variety of governance structures all reflecting the desire to treat the federal capital in a manner different from that used for the governance of other cities within the country. The relationship between the federal government and the capital city government becomes a hugely significant issue: while the interests of the local inhabitants are important, they need to be weighed against the interests of states and major cities in the federation, against the special symbolic value to the nation of its lead city, and against the need to ensure the smooth running of the federal government itself. There will be costs arising from the very fact of being the federal capital that will not be experienced by other cities, and dealing with them will present delicate policy problems. Questions that emerge from all this (from Slack \& Chattopadhyay 2009: 4-5) include:

- Who is responsible for making decisions?

- Is the capital city responsible to a provincial or state government or directly to the federal government?

- Who is responsible for providing which services?

- How are these services financed?

- Does the federal government compensate the capital city for the costs associated with being the capital? 
Questions such as these are surveyed comprehensively in the case studies in the Slack/Chattopadhyay volume, as they were in the Rowat volume 30 years ago. Where cities covered by Rowat get fresh attention, there is much updating in the new work; and of course there are (as indicated above) several newcomers receiving this attention for the first time. Though they were far from neglected by Rowat and his colleagues, arguably the financial issues receive fuller treatment in Slack/Chattopadhyay. And each case study in Slack/Chattopadhyay concludes very usefully with a discussion of 'emerging issues' for that capital.

The case studies in Slack/Chattopadhyay are arranged alphabetically according to country rather than city names, and so the Australia-Canberra study by University of Technology Sydney (UTS) academic Graham Sansom takes pride of place. The chapter (Sansom 2009) opens with a historical overview, followed by major sections on governance structure, the distribution of roles and responsibilities between the federal government and the city government (which in this case is of course that of the Australian Capital Territory, or ACT), ${ }^{2}$ and financing, all leading up to the 'emerging issues' conclusion. This sequence is repeated in the other case studies (with minor adaptations), facilitating comparisons among the eleven cities.

Sansom traces the origins of Canberra in the Australian federal compact of 1901, the critical provision for present purposes requiring that the city be situated between Melbourne and Sydney, not closer than 100 miles to Sydney and in a special federal territory to be excised from the surrounding state and placed under federal administration. $^{3}$ Some significant statements of the early period - through to the laying of a foundation stone and the naming of the city in 1913 - are quoted, demonstrating the high symbolism quotient built into the early planning initiatives. ${ }^{4}$ The slow early

\footnotetext{
${ }^{2}$ For non-Australian readers, it should be explained that the federal territory, now the Australian Capital Territory, consists of the City of Canberra, a small agricultural area, and a much larger mountainous rump arranged as a national park.

${ }^{3}$ The story of the selection of the site for the federal capital, the slow development of federal territory thereafter under what amounted to a form of colonial administration, and the eventual move to selfgovernment (in 1989) is told in detail in Grundy et al 1996. From an administrative point of view, the site had to be virtually virgin territory: New South Wales would not join the federation if Melbourne became the capital, Victoria would not join if Sydney became the capital, and the other four prospective states would not join if either Sydney or Melbourne became the capital.

${ }^{4}$ It is likely that flamboyant minister King O'Malley trumped those quoted, when he declared (1903): "this is the first opportunity we have had of establishing a great city of our own ... I hope that ... the children of our children will see an Australian federal city that will rival London in population, Paris in beauty, Athens in culture, and Chicago in enterprise". However others like Prime Minister Alfred Deakin had a much more frugal view: see Chapter 3 of Grundy et al 1996 ("Creating a National Place").
} 
development and the post-World War II speed-up are covered, along with all the planning challenges that speed-up brought about. Any semblance of conventional local government disappeared when New South Wales transferred the territory to the Commonwealth, and the governmental structure remained comparatively uncomplicated (though not trouble-free!) after the conferring of self-government in 1989, with a single ACT government performing both state-type and municipal functions and relating closely to the Commonwealth government, co-located in the same city as the ACT government. The chapter includes an excellent survey of the financial aspects of Canberra governance, the discussion noting inter alia transfer problems resulting from the myriad cross-border connections between the ACT and surrounding areas of New South Wales and the heavy dependence on Commonwealth financial support. ${ }^{5}$

Across the eleven federal capitals surveyed in the Slack/Chattopadhyay book, there are many similarities and many points of difference, and at least half-a-dozen ways of attempting to sort them emerge. Were they long-standing administrative centres which simply assumed federal-capital duties at some stage during their evolution, or were they established from the start as federal capitals, at some distance from other administrative centres? Are they big or small in relation to other cities in the country concerned? Are their communities mono-lingual or bi/multi-lingual, and mono-cultural or bi/multi cultural? In governance terms, do they remain part of the surrounding province or state or are they constituted as a special federal district. If the latter, do they have their own separate governing institutions or are they governed as a part of the federal administration? And if they do have their own institutions, how are powers and responsibilities distributed between them and the federal institutions? Within them, is there or is there not a subordinate tier of local governments? And, in finance terms, are they capable of raising most of their own revenues or, if not, how are the dependencies on federal payments arranged? In particular, to what extent are the federal payments aimed at compensating them for the additional costs they occur in functioning as federal capitals?

\footnotetext{
${ }^{5}$ Among the 'emerging issues', the chapter observes that a "more important question for the ACT is how it will fare in the evolution of Australia's federal system as a whole" (Sansom 2009: 31). Amen to that! But what it does not do is to note a view first expressed around the time that the Northern Territory was gaining self-government and the ACT slowly evolving towards it: that the two internal territories could provide a model for a possible reconstruction of the whole edifice of Australian government, involving elimination of the states and their replacement by a set of (say 100) regional governments with significant governmental power in their own right but lacking the sovereignty of the foundation states and all that went with that (see eg Power \& Wettenhall 1976: 124-125; Wettenhall 2009: 59).
} 
The eleven case studies provide a wealth of information on such issues, and only a few highlights emphasising some points of comparison are noted here. Thus Addis Ababa, Brussels, Berlin and Mexico City are the largest cities and major economic centres in their respective countries. New Delhi is also a large metropolis, but not the largest in India. In contrast, Canberra, Bern, Ottawa and Washington are relatively small within their national contexts, their character largely determined by their federal capital role. Brasilia would be in this group too, but it is strangely omitted from this collection. Brussels and Ottawa are notable as multi-lingual, multi-cultural cities, and Brussels is fairly distinctive (with Addis Ababa, not often noted in federalism studies) as a host to many international institutions.

Brussels figures again with what is probably the most highly complex governing structure, with separate but overlapping region and community governments and a subsidiary network of 19 municipalities - described rather softly as a "somewhat cumbersome governance arrangement" (van Wynsberghe 2009: 48). Mexico City, New Delhi and some others either have a smaller number of internal local governing units or a single local government structure separate from the capital territory structure and sharing powers with it. At the other end of this spectrum, Berlin, Canberra and Washington have no internal local government structure separate from the territorial government system though Donald Rowat several times urged that the Canberra "solution" was defective for this reason (Rowat 1990: 483; 1991: 42-43; 1993: 157; 1997: 549-550). Ottawa and Bern present another pattern: they are established local government units within one of the regular provinces of the federation. But in the matter of federal capitals, nothing can ever be quite so simple: on the one hand, Ottawa is a conurbation that extends effectively into a neighbouring province with separate municipal arrangements, and it shares with others the strong interest and supervision of a national government development or planning commission.

In the matter of federal-capital city financial arrangements, Brussels is again fairly distinctive, with a "cooperation agreement" providing for federal funding to promote its international role and its performance of capital city functions (van Wynsberghe 2009: 42-43). The pattern may not be as clear for some of the other capitals, but there is usually some sort of compensatory arrangement (for comparisons, see Table 22.6 in 
Slack \& Chattopadhyay 2009: 316-317). ${ }^{6}$ Here Washington is distinctive and possibly more heavily controlled: after a spell of notably unsound fiscal practices leading to the insolvency of the District of Columbia in 1995, the federal government took over the district's finances and established a position of Chief Financial Officer independent of the DC government (Gandhi et al 2009: 264).

A final classification offered by the editors is that which distinguishes between federal districts, city-states, and "cities in a state" (Slack \& Chattopadhyay 2009: 297-304). Ottawa, Bern and the South African twins are fairly obvious examples of the last. Washington and some of the others are also fairly obviously federal districts, while Brussels and Berlin qualify under their countries' constitutions as states - hence it is appropriate to regard them as city-states. Where does this leave Canberra? The editors see it also as a federal district, but in the view of this reviewer (Wettenhall 1998a, 1998b; Halligan \& Wettenhall 2002 - noted and I think largely accepted by the contributor of the Canberra case study, Sansom 2009: 16), it deserves to be classified as a city-state (or at least a quasi-state). Its governance arrangements bring it, and for this purpose the companion Northern Territory, close in most respects to an Australian constitutional state. But this is a minor quibble.

There is all this and much more in the Slack-Chattopadhyay book. It is a mine of information and insights about the governance and financing of federal capitals, and so a worthy successor to Rowat's path-breaking book written and published almost 40 years ago. But Rowat's book is still important, and it should be retained, valued, and shelved alongside Slack \& Chattopadhyay in any serious library.

\section{References:}

Gandhi, Natwar MN, Yilmaz, Yesim, Zahradnik, Robert \& Edwards, Marcy 2009. 'Washington, District of Columbia, United States of America’, in Slack \& Chattopadhyay (eds) 2009: 264-291.

Grundy, Philip, Oakes, Bill, Reeder, Lynne \& Wettenhall, Roger 1996. Reluctant Democrats: The Transition to Self-Government in the Australian Capital Territory, Federal Capital Press, Canberra.

Halligan, John \& Wettenhall, Roger 2002. ‘A City-State in Evolution’, Canberra Bulletin of Public Administration, no.103: 3-10.

\footnotetext{
${ }^{6}$ As the editors point out, compensations come in other ways apart from the federal transfer payments, including greater availability of high-quality jobs, higher city prestige, usually better provision of infrastructure and cultural facilities, and the increased tourism flowing from the above (Slack \& Chattopadhyay 2009: 296).
} 
Power, John \& Wettenhall, Roger 1976. 'Regional Government vs Regional Programs’, Australian Journal of Public Administration, 35(2): 114-129.

Rowat, Donald C (ed.) 1973. The Government of Federal Capitals, University of Toronto Press, Toronto.

1990. Review of Rae Else-Mitchell \& Philip Grundy (eds), Canberra: A People's Capital, in Australian Journal of Public Administration, 49(4): 483.

1991. 'Canberra in International Perspective: The Government of Federal Capitals', in WK Oakes \& LJ Reeder (eds), Governing the Two Canberras: Canberra as Federal Capital and Canberra as a Place to Live, Centre for Research in Public Sector Management, University of Canberra: 28-65.

1993. 'Ways of Governing Federal Capitals', in Taylor, Lengellé \& Andrew (eds) 1993: 149-171.

1997. Review of Grundy, Philip, Oakes, Bill, Reeder, Lynne \& Wettenhall, Roger 1996. Reluctant Democrats: The Transition to Self-Government in the Australian Capital Territory, in Canadian Public Administration, 40(3): 549-550.

Sansom, Graham 2009. ‘Canberra, Australia’, in Slack \& Chattopadhyay (eds) 2009: 11-32.

Slack, Enid \& Chattopadhyay, Rupak (eds) 2009. Finance and Governance of Capital Cities in Federal Systems, McGill-Queen's University Press, Montreal \& Kingston.

Taylor, John, Lengellé, Jean G \& Andrew, Caroline (eds) 1993. Capital Cities: International Perspectives, Carleton University Press, Ottawa.

van Wynesberghe, Caroline 2009. ‘Brussels, Belgium’, in Slack \& Chattopadhyay (eds) 2009: 34-53.

Wettenhall, Roger 1998a. 'Governing the ACT as a Small Quasi-State', Canberra Bulletin of Public Administration, no.87: 8-20. 1998b. "The External Relations of a Small Quasi-State within a Federal System: The Case of the Australian Capital Territory", Public Administration and Development, 18(2): 123139.

2009. 'Twenty Years of ACT Self-Government: Some Governance Issues', Public Administration Today, Issue 18: 58-71. 